\title{
Олена СиняВська
}

\section{ПЕДАГОГІЧНА ДІЯЛЬНІСТЬ І. С. ОРЛАЯ: НОВАТОРСТВО, ЩО ВИТРИМАЛО ВИПРОБУВАННЯ ЧАСОМ}

Видатний український вчений Іван Семенович Орлай відомий в Україні та за иї межами як мінімум двома гранями своєї активної діяльності - як доктор медицини і лікар та як один із провідних організаторів освітянської діяльності. Він не тільки продукував, а і втілював в життя передові педагогічні ідеї, намагаючись знаходити новаторські підходи до реформування навчальних закладів у першій третині XIX ст. Пройшло майже 200 років, але проблеми модернізації освіти продовжують залишатися такими ж актуальними. Адже важливо не тільки де і кого навчають, а чому і як навчають.

Постать героя нашого допису вже з середини XIX ст. привертала увагу дослідників - про нього писали невеличкі статті та огляди, публікували його твори, вивчали наукові погляди та педагогічну діяльність. Із всього розмаїття історіографічного матеріалу і виходячи з досліджуваної теми виділимо декілька найважливіших праць. Однією з перших праць про I. Орлая був нарис відомого російського письменника Нестора Кукольника «И. С. Орлай» у ювілейному виданні, присвяченому пам'яті графа О. Г. КушелєваБезбородька «Лицей князя Безбородко» [7]. Один 3 найталановитіших випускників детально викладав біографію свого вчителя, вченогоенциклопедиста, розкривав внесок у становлення та розвиток знаменитого навчального закладу. Серед значних наукових видань XX ст. найвагомішим є дослідження словацької дослідниці українського походження Тамари Байцури «Иван Семенович Орлай: жизнь и деятельность» [1]. Ії монографії притаманне різностороннє висвітлення діяльності I. С. Орлая в усі періоди його життя. Із сучасних досліджень окремо слід виділити кандидатську дисертацію Доброскок Ірини Іванівни «Освітньо-педагогічна діяльність Івана Семеновича Орлая (1770-1829 рр.)», успішно захищену в Інституті вищої освіти Академії педагогічних наук України у 2005 р. Дисертацію присвячено дослідженню науково-просвітницької діяльності, зокрема, наукової, педагогічної, освітньої, громадської та культурної спадщини I. С. Орлая.

У статті ставиться мета дослідити новатор- ські ідеї Орлая та втілення їх в життя на прикладі двох навчальних закладів, в яких працював педагог - Ніжинської гімназії вищих наук та Рішельєвського ліцею в Одесі.

\section{Шлях до педагогіки}

Іван Орлай (Орлаі де Карбі, Орлаян) народився в 1771 р. в селі Паледь колишньої АвстроУгорщини (тепер Мукачівський район Закарпатської області) у сім'ї збіднілих дворян [10]. Розпочинав навчання Іван Орлай, згідно 3 тодішніми вимогами австро-угорської системи освіти, у мукачівській елементарній школі з українською мовою викладання. У 1779 р. хлопчика віддали до Ужгородського народного училища 3 латинською мовою навчання, потім у 1782 р. він вступає і через три роки закінчує курс місцевої гімназіі. Можливостей для подальшого продовження освіти в Ужгороді, невеликому тоді містечку, не було. Орлаі де Карбі переїжджає до міста Орадя (зараз Румунія), де навчається у Варадинській академії і здобуває повну середню освіту. Сдиним вищим навчальним закладом в підавстрійській Україні, де Іван Орлай, який вважав себе карпатським русином, міг здобути освіту, був Львівський університет. Тут і навчався три роки майбутній педагог на філософському факультеті. У 1789 р. І. Орлай вступив в Йозефінську семінарію і став членом ордену піарістів (заснований у 1597 р. римсько-католицький орден).

Після одержання звання професора (1790р.) Орлай розпочав педагогічну діяльність у ВеликоКарлівській гімназії, викладав давні мови, географію, історію та арифметику у нижчих класах. Та не довго він утримався на посаді викладача. Ректор-єзуїт відмовився продовжити контракт 3 молодим вченим, адже той був «русином» (закарпатським українцем) за походженням [6]. 1791 р. Орлай змушений був переїхати до Росії, до Петербургу. Тут він змінює своє прізвище спочатку на Орлов, а потім на Орлай [1, с. 17]. Провчившись два роки в медичному училищі, після його закінчення удосконалював знання 3 медицини у Відні. Діяльність у Росії розпочав на посаді лікаря, згодом - вченого секретаря Медичної Колегії та редактора «Журнала врачебной 
науки» (1811-1814 рр.). Протягом двох десятків років він працював ординатором у Генеральному сухопутному госпіталі, лікарем у Семенівському полку, постійно знайомився 3 новітніми досягненнями в медицині, досліджував проблеми, пов'язані $з$ лікуванням віспи, раку, ревматичної епілепсії тощо, викладав у медичних навчальних закладах, був гоф-медиком царя Олександра I [9].

Його внесок у розвиток науки був відзначений не лише російською, а й світовою громадськістю. І. Орлай - доктор медицини та хірургії Дерптського університету, доктор філософії, магістр словесних наук Кенігсбергського університету, учений секретар Державної медичної Колегії в Петербурзі, почесний член Російської Імператорської академії наук, Віленського Медичного товариства, Иенського фізичного товариства, Альтенбурзького Ботанічного товариства. За участь у Вітчизняній війні 1812 р. Іван Семенович Орлай був нагороджений орденом і бронзовою медаллю.

На початку 1817 р. стан здоров'я Івана Семеновича погіршився і він був змушений на два роки припинити будь-яку трудову діяльність. Клімат Петербурга не сприяє його одужанню, й під впливом багатьох обставин (фінансові труднощі, складні службові стосунки), після тривалих коливань і роздумів він залишає медичну службу. Незважаючи на привабливі пропозиції з Московського та Харківського університетів, І. Орлай вибирає шлях педагога і до кінця життя залишається пов'язаний з розвитком освіти в Україні. Роки діяльності в Ніжинській гімназії й Одеському Рішельєвському ліцеї можна вважати роками розквіту його педагогічного таланту.

\section{Ніжинський період:}

\section{перші новаторські спроби}

Організаторські здібності та педагогічний талант I. Орлая яскраво розкрилися у Ніжинській гімназії. Натхненний глибокими патріотичними почуттями, він свої знання і талант присвятив розвитку та удосконаленню гімназії, перетворенню її в один з найкращих вищих навчальних закладів. В Ніжин I. С. Орлай потрапляє у 1821 року після трагічної смерті першого директора гімназії, свого земляка та друга, також вихідця із Закарпаття, Василя Кукольника.

Ніжинська гімназія вищих наук створювалася як привілейований навчальний заклад, право вступу до якого мали діти малозабезпечених дворян - вихідців з родин української козацької старшини. Заснована 1805 р. на кошти українських меценатів, російських державних діячів братів Олександра Андрійовича та Іллі Андрійовича Безбородьків, Гімназія давала університетську енциклопедичну освіту. Курс навчання був розрахований на 9 років. Шість років учні навчалися за гімназійною програмою, а останні три роки опановували університетський курс.

Саме тут Орлай повернувся до педагогічної діяльності. Оскільки Статуту гімназії на той час ще не існувало, він, насамперед, обгрунтував порядок керівництва гімназією та відразу ж розпочав реорганізацію навчально-виховного процесу на гуманістичних принципах філософськогуманітарної та правової освіти. У навчанні I. С. Орлай прагнув впровадити методи видатного швейцарського педагога Йоганна Песталоцці, вельми популярного тоді в Європі педагога, головним в системі якого було положення про необхідність встановлення взаєморозуміння між учнями i вчителями. Н. Кукольник період управління I. С. Орлая називав «самим блискучим періодом в історії гімназії», а самого директора характеризував дуже позитивно: «Чоловік істинно вчений і освічений, він умів вдихнути в вихованців дух вищої допитливості, дати їм необхідну частку незалежності, не полишаючи разом 3 тим непомітно своїм батьківським керівництвом» [7, с. 18].

Маючи багаторічний досвід науковопедагогічної роботи у Медико-хірургічній академії, Орлай керував гімназією з властивим йому демократизмом. Його стиль управління відзначався глибокою продуманістю та ретельністю. Особливо виважено підходив до добору педагогів, слідкував щоб вони мали право викладати «в університетах, академіях, ліцеях». Залучив до викладацької роботи низку прогресивних та талановитих педагогів.

У Ніжинській гімназії І. С. Орлай запровадив методи розвиваючого навчання з елементами змагальності учнів. Навчальні групи комплектувалися за результатами іспитів; іноземні мови викладалися в особливих відділеннях, де навчалися гімназисти $з$ приблизно однаковим рівнем лінгвістичних навичок. Найбільш успішні студенти займали на конкурсній основі місця «старших» в групах і відділеннях. Проблеми, що виникали під час викладання, обговорювалися на спеціальних конференціях викладачів (своєрідних педагогічних нарадах). Був відкритий прийом до вищих класів гімназії, програми яких 3 окремих предметів відповідали університетським.

Безперечною заслугою I. С. Орлая є розроблення та прийняття Статуту гімназії (1825 р.), де зазначалося, що гімназія - це «публічний навчальний заклад, який займає перше місце після університетів...». Педагог-демократ значно розширив контингент гімназистів за рахунок вільних слухачів, які на відміну від пансіонерів, навчалися безкоштовно. Кількість гімназистів постійно зростала: якщо у 1821 р. навчалося лише 41 чол., то у 1826 році - вже 250 [6]. За роки дире- 
кторства I. С. Орлая значно зріс авторитет навчального закладу.

3 досвіду начально-виховного процесу Ніжинської гімназії І. С. Орлай написав декілька праць педагогічного спрямування, програмовою серед яких є праця «Мнения о преобразовании училищ в России» (1825 р.). Значна частина його наукового доробку залишилася у рукописах, але саме ця стаття була опублікована в дослідженні з історії гімназії професора Ніжинського Історикофілологічного інституту Є. Пєтухова у 1879 р. $[2$, c. 28$]$.

Ця стаття є роздумами Орлая про шляхи реформування освіти. Педагогічні погляди, що обстоював педагог, грунтувалися на глибокому знанні системи європейської освіти, яку він прагнув запровадити i у Росії. Автор пропонував створити струнку та послідовну систему освіти від початкових училищ до університетів, висловлювався про необхідність грунтовної освіти для молодої генерації. Значне місце у системі освіти він відводив ліцеям як сполучній ланці між середньою та вищою освітою, а от приватні пансіони, які здебільшого існували у комерційних цілях, I. С. Орлай вважав неприпустимими. Особливе значення він надавав зв'язку навчання 3 потребами окремих регіонів, рекомендував в губернських гімназіях вивчати мови тих народів, представники яких там проживали. Ще одна важлива ідея педагога - запровадження рівних можливостей на здобуття освіти, як середньої, так і вищої, для усіх верств населення - частково була втілена в його одеський період.

Рішельєвський ліцей: реформи, продиктовані часом

Указом від 12 серпня 1826 р. І. С. Орлай був призначений директором Рішельєвського ліцею.

Рішельєвський ліцей в Одесі заснований у 1817 році за ініціативи бувшого градоначальника Одеси герцога А.-Е. Рішельє. До складу ліцею входили: початкове училище, власне ліцей 35 класів по два роки навчання в кожному, два середніх училища з вивченням в одному з них правознавства і політичної економії, а в другому комерційних наук та педагогічний інститут, вихованці якого залишалися при ліцеї. У перше десятиліття існування ліцей був навчальним закладом закритого типу - тут навчалися діти аристократів. Він умовно поділявся на «внутрішній» для пансіонерів та «зовнішній» для учнів, які проживали в місті. Першими директорами ліцею були французи - відомий єзуїт абат Ніколь та його наступник Ремі Жиллє [3, с. 27-30].

Новий директор отримав широкі повноваження. Прибувши до Одеси, він відвідав засідання правління Рішельєвського ліцею, де відразу запропонував здійснити переформатування керівництва за зразком Ніжинської гімназії - ви- ділити в окремі підрозділи господарське правління і правління $з$ навчальної частини, запровадити посаду вченого секретаря, нові форми діловодства, зобов'язати викладачів та вихователів складати щомісячні звіти про свою роботу. Всі розпорядження нового директора були підтримані керуючим ліцеєм графом Віттом.

На початку січня 1827 року I. С. Орлай підготував проект нового Статуту ліцею [4, арк. 218 зв.]. На його думку, Рішельєвський ліцей мав за змістом освіти відповідати двом університетським факультетам (філософському i юридичному) і призначатися для вивчення «вищих наук», яким повинні навчати 8 професорів і 2 ад'юнкт-професора. Проект I. С. Орлая передбачав загальну реорганізацію навчального закладу в три частини: власне ліцею, гімназії та початкового училища. Власне ліцей мав складатися 3 двокласних філософського та політикоюридичного відділень. У чотирикласній гімназії при ліцеї могли навчатися діти «будь-якого вільного стану», викладацький корпус складався 3 законовчителя, старших і молодших вчителів i вчителя малювання. У початковому училищі мали навчати вихованців «підготовчим наукам» i3 застосуванням Ланкастерської методики взаємного навчання.

Термін перебування в кожному класі відповідно проекту зменшувався 3 двох років до одного року (тривалість навчальних курсів визначалася так: в початковому училищі - 3 роки, а в гімназії та ліцеї - по 4 роки), а початок навчання переносився 31 січня на 1 серпня, подібно іншим освітнім установам. Іспити передбачалося розділити на приватні, які проводилися б один раз на півріччя, і публічні - раз на рік. На підставі публічних іспитів учні могли переводитися в вищі класи.

Важливим нововведенням, передбаченим проектом Статуту, була система навчання мовам, абсолютно окремо від інших навчальних предметів. Для цього пропонувалося утворити шість відділень: початкове, граматичне, синтаксичне, риторичне, естетичне i відділення піїтики, де вихованці ліцею і гімназії могли б вивчати мови спільно. Пріоритетними у такому випадку ставали саме знання, а не статус чи вік вихованців. Нова навчальна програма частково впроваджувалася в ліцеї з грудня 1827 року, а остаточно була затверджена міністерством освіти в лютому 1828 року [5, арк. 1-4].

Істотне значення мало те, що І. С. Орлай вирішив відмовитися від суворої ізоляції вихованців «внутрішнього» ліцею від учнів «зовнішніх класів». Їх об'єднання для спільного навчання означало руйнування закритого характеру ліцею. Внаслідок цих змін кількість пансіонерів ліцею скоротилася і після 1828 року вже не перевищувала 65-66 осіб; натомість кількість «зовні- 
шніх» вихованців збільшилася до 216 осіб у 1828 році, 230 осіб у 1830 році, 313 осіб у 1832 році [8, с. 101-102].

Велику увагу директор приділяв кадровому питанню. І. С. Орлай відмовився від практики обов'язкової служби в ліцеї випускників Педагогічного інституту. У 1829 році його вихованці здобули дозвіл разом з пансіонерами продовжувати освіту на філософському чи юридичному відділенні ліцею. Натомість він багато зусиль витрачав на пошуки педагогів, віддаючи перевагу молодим університетським випускникам, які могли запропонувати новації в змісті та формі навчання вихованців ліцею.

I. С. Орлай помер 27 лютого 1829 року.

Педагогічні погляди, які він обстоював та впроваджував у Ніжинській гімназії та Рішельєвському ліцеї, витримали випробування часом. Модель навчального закладу, яку створив I. С. Орлай, втілюючи свої просвітницькі ідеї, дала глибоке коріння: і гімназія в Ніжині, і ліцей в Одесі стали регіональними центрами підготовки інтелектуальних кадрів, формування інтелігенції. А новаторські підходи І. С. Орлая до керівництва освітніми установами, формування навчальних програм та втілення їх в життя стали важливим кроком на шляху перетворення їх на вищі навчальні заклади.

\section{СПИСОК ВИКОРИСТАНИХ ДЖЕРЕЛ}

1. Байцура Т. Иван Семенович Орлай. Жизнь и деятельность / Тамара Байцура. - Братислава : Словац. пед. изд-во ; Пряшев: Отд-ние укр. лит., 1977. - 235 с.

2. Гимназия высших наук князя Безбородко в Нежине (к 75-летию со дня основания) : исторический очерк / Е.В. Петухов. - Спб : Типография В. С. Балашева, 1895. -63 с.

3. Грєбцова I. С. Рішельєвський ліцей як попередник університету в Одесі / Грєбцова I. С., Синявська О.О.// Одеський національний університет імені I. I. Мечникова: історія та сучасність (1865-2015) / кол. авт. ; гол. ред. І. М. Коваль. - Одеса : ОНУ, 2015. - С. 21-56.

4. Держархів Одеської обл. - Ф. 44 (Рішельєвський ліцей). - Оп. 1 (1827). - Спр. 1 (Донесення щодо Статуту, штатах і стану Рішельєвського ліцея).

5. Держархів Одеської обл. - Ф. 44 (Рішельєвський ліцей). - Оп. 1 (1828). - Спр. 34 (Журнал засідань правління навчальної частини).

6. Іван Семенович Орлай - подвижник української освіти [Електронний ресурс] - Режим доступу : https://library.ndu.edu.ua/index. php/diyalnist-biblioteki/2015-02-17-14-30-21/ item/26-ivan-semenovych-orlai (останній перегляд: 19.04.2018)

7. Лищей князя Безбородко / издал Г. А. КушелевБезбородко. - СПб. : В типографии Императорской Академии Наук, 1859. - 208 с.
8. Михневич И. Г. Исторический обзор сорокалетия Ришельевского лицея, с 1817 по 1857 г. / Михневич И. Г. ; сост. инспектором лицея Иосифом Михневичем. - Одесса : в типографии Л. Нитче, 1857. - 200 с.

9. Пироженко Л. Орлай Іван Семенович [Електронний ресурс] / Пироженко Л. - Режим доступу : http://ru.osvita.ua/vnz/reports/ pedagog/1226/ (останній перегляд: 19.04.2018).

10. Скрипник П. І. Орлай Іван Семенович [Електронний ресурс] / Скрипник П. І. - Режим доступу : http://www.history.org.ua/?termin= Orlaj_I (останній перегляд: 19.04.2018)

\section{REFERENCES TRANSLATED AND TRANSLITERATED}

1. Baitsura T. Yvan Semenovych Orlai. Zhyzn y deiatelnost / Tamara Baitsura. - Bratyslava : Slovats. ped. yzd-vo ; Priashev: Otd-nye ukr. lyt., 1977. - 235 c.

2. Hymnazyia vysshykh nauk kniazia Bezborodko v Nezhyne (k 75-letyiu so dnia osnovanyia) : ystorycheskyi ocherk / E. V. Petukhov. - Spb : Typohrafyia V. S. Balasheva, 1895. -63 s.

3. Hriebtsova I.S. Rishelievskyi litsei yak poperednyk universytetu v Odesi / Hriebtsova I. S., Syniavska O. O. // Odeskyi natsionalnyi universytet imeni I. I. Mechnykova: istoriia ta suchasnist (1865-2015) / kol. avt. ; hol. red. I. M. Koval. - Odesa : ONU, 2015. S. 21-56.

4. Derzharkhiv Odeskoi obl. - F. 44 (Rishelievskyi litsei). - Op. 1 (1827). Spr. 1.

5. Derzharkhiv Odeskoi obl. - F. 44 (Rishelievskyi litsei). - Op. 1 (1828). Spr. 34.

6. Ivan Semenovych Orlai - podvyzhnyk ukrainskoi osvity [Elektronnyi resurs]. Rezhym dostupu : https://library.ndu.edu.ua/ index.php/diyalnist-biblioteki/2015-02-17-1430-21/item/26-ivan-semenovych-orlai (ostannii perehliad: 19.04.2018).

7. Lytsei kniazia Bezborodko / yzdal H. A. Kushelev-Bezborodko. - SPb. : V typohrafyy Ymperatorskoi Akademyy Nauk, 1859. - $208 \mathrm{~s}$

8. Mykhnevych Y.H. Ystorycheskyi obzor sorokaletyia Ryshelevskoho lytseia, s 1817 po 1857 h. / Mykhnevych Y.H. ; Sostavlen ynspektorom lytseia Yosyfom Mykhnevychem. Odessa : v typohrafyy L. Nytche, 1857. - 200 s.

9. Pyrozhenko L. Orlai Ivan Semenovych [Elektronnyi resurs] / Pyrozhenko L. - Rezhym dostupu : http://ru.osvita.ua/vnz/reports/ pedagog/1226/ (ostannii perehliad: 19.04.2018).

10. Skrypnyk P. I. Orlai Ivan Semenovych [Elektronnyi resurs] / Skrypnyk P. I. - Rezhym dostupu : http://www.history.org.ua/?termin=Orlaj_I (ostannii perehliad: 19.04.2018) 